\title{
Effects of Work Discipline, Work Motivation and Compensation on Employees Performance at Sekretariat Direktorat Jenderal Perhubungan Udara
}

\author{
Frista Dearetha Marasabessy \\ Universitas Mercu Buana, Jakarta
}

\begin{abstract}
This study aims to analyse the effects of work discipline, work motivation, and compensation on employees performance. The objects of this study are employees working at the Sekretariat Direktorat Jenderal Perhubungan Udara. The populations were 333 employees. The sample of 77 respondents was obtained by using Slovin's formula with $10 \%$ error. The sampling method used was proportional stratified random sampling. Data were analysed by using multiple linear regression. The results show that work discipline, work motivation, and compensation have significant and positive effects to employees performance. Work motivation has the biggest influence on employees performance.
\end{abstract}

Keyword:- Work Discipline, Work Motivation, Compensation, Employee Performance

\section{INTRODUCTION}

Employee performance is a measure on the results of employee's work. The growth of the air transportation sector will reflect economic growth directly so that transportation has an important and strategic role, both macro and micro.

Human resources are one of the important assets for an organization because they are important as drivers for competitive advantage and determinants of all organizational activities.

The development of sustainable air transportation is the duty of the government for improving the people's economy. To carry out the development of air transportation, it is necessary to have a professional, highly dedicated and integrated employees.

Realization of program activities that experience fluctuations and assessment of employee work behavior that is not optimal does not merely happen, there are several factors that can affect the performance of employees.

\author{
Singmin Johanes Lo \\ Universitas Mercu Buana, Jakarta
}

\section{THEORETICAL REVIEW}

\section{A. Work Discipline}

According to Handoko (2008: 208) discipline is a management activity to carry out organizational standards. The purpose of discipline is to improve future activities rather than punish past activities. While the goals of disciplinary action should be positive, educative and correcting, not negative actions that bring down employees who do wrong. Discipline is one's awareness and willingness to obey all company regulations and social norms that apply (Hasibuan, 2014: 193).

Hasibuan (2014: 194) suggests indicators that affect the level of employee discipline in an organization, including:

$>$ Purpose and Ability

$>$ Leadership Model

$>$ Remuneration

$>$ Justice

$>$ Built in Control

$>$ Penalties

$>$ Decisiveness, and

$>$ Human Relations.

\section{B. Work motivation}

According to Nawawi (in Alwi, 2017: 75) the word motivation is basically the word motive which means encouragement, cause or reason for someone to do something. Hasibuan (2014: 143) defines motivation as providing the driving force that creates the excitement of one's work so that they want to work together, work effectively, and be integrated with all their efforts to achieve satisfaction.

Robbins and Judge (2015: 112) define motivation as a process that explains the strength, direction, and perseverance of a person in an effort to achieve goals.

The purpose of motivation according to Hasibuan (2014: 146), namely:

> Increase employee morale and job satisfaction;

$>$ Increase employee productivity;

$>$ Maintaining the stability of company employees;

$>$ Increase employee discipline;

$>$ Making employee procurement effective;

$>$ Creating a good atmosphere and working relationships;

> Increase employee loyalty, creativity, and participation; 
Increase the level of employee welfare;

$>$ Enhance employees' sense of responsibility towards their duties;

Increase the efficiency of using tools and raw materials.

According to Herzberg (in Siagian, 2009: 107), that employees are motivated to work due to two factors, namely:

$>$ Intrinsic factor, namely the driving force that arises from each employee, in the form of:

- Achieve something

- Acknowledgment obtained

- The nature of the work performed

- Convenience

- Responsibility

- Career progress

- Professional and intellectual growth

Extrinsic factor is a driving factor that comes from outside oneself, especially from the organization where he works. These extrinsic factors include:

- Organizational policy

- Implementation of established policies

- Supervision by superiors

- Interpersonal relationships

- Work environment.

\section{Compensation}

According to Hasibuan (2014: 118) which states that compensation is all income in the form of money, direct or indirect goods received by employees in return for services provided to the company.

Nurjaman (2014: 182) believes that compensation is a form of reward or remuneration given by the company to its employees, both in the form of financial and goods and services so that employees feel valued at work. Kasmir (2016: 235) said that compensation is an employee's right for his services to help the company achieve its goals.

The concept of compensation contains a very broad scope not only for the provision of salaries and wages. The concept of salary and wages only emphasizes financial rewards, while compensation includes financial and nonfinancial rewards. Rivai (2014) states that compensation is divided into two, as follows:

\section{Financial Compensation}

Financial compensation consists of two, namely direct compensation and indirect compensation (allowances).

- Direct financial compensation consists of basic payments (salary, wages), achievement payments, incentive payments, commissions, bonuses, profit share, stock options, while the deferred includes old-age savings, cumulative shares.

- Indirect financial compensation consists of protection which includes insurance, severance pay, children's schooling and pensions. Compensation outside working hours includes overtime, holidays, sick leave, maternity leave, while based on facilities include housing, moving costs and vehicles.

\section{Non-financial Compensation}

Non-financial compensation consists of careers, promotional opportunities, recognition of works, new discoveries, special achievements, while the work environment includes being able to praise, be friendly, comfortable on duty, be pleasant and conducive.

\section{Employee Performance}

Abdullah (2014: 3) says performance is a picture of the level of achievement of the implementation of a program of activities or policies in realizing the goals, objectives, vision and mission of the organization as outlined through the strategic planning of an organization. Another understanding of performance according to Kasmir (2016: 182) is simply "Work results and work behaviors that have been achieved in completing tasks and responsibilities given within a certain period". From this understanding in performance implies that performance is the result and work behavior of a person within a period, usually 1 year.

\section{Employee Performance Dimensions and Indicators}

According to Dessler (2011: 340) performance can be measured through the following dimensions and indicators:

$>$ Quality of work is accuracy, accuracy, and is acceptable for the work done.

$>$ Productivity is the quantity and efficiency of work produced within a certain time period.

$>$ Job knowledge is practical / technical skills and information used on the job.

$>$ Reliable is the extent to which an employee is reliable or completes and follows up on tasks.

$>$ Attendance is the extent to which employees are on time, observing specified time / meal periods and overall attendance records.

$>$ Independence is the extent to which work is carried out with or without supervision.

\section{E. Conceptual Framework}

The research hypothesis are as follows:

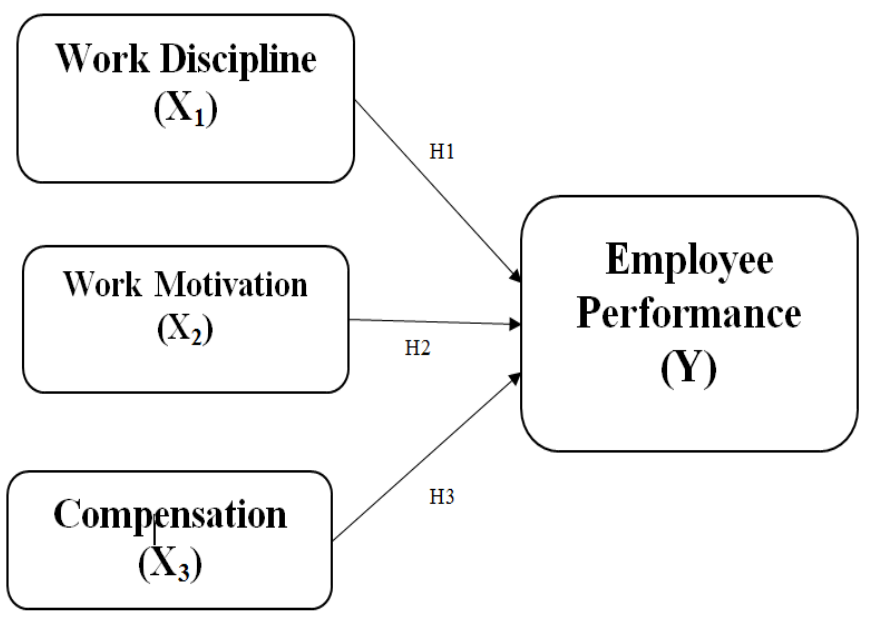

Fig 1:- Conceptual Framework 
H1: Work discipline has significant and positive effect on employee performance

$\mathrm{H} 2$ : Work motivation has significant and positive effect on employee performance

H3: Compensation has significant and positive effect on employee performance

\section{RESEARCH METHOD}

The type of research is quantitative method. The population was 333 and the size of sample using Slovin formula of 77 respondents. Primary data were obtained from questionnaires distribute directly to employess at the Sekretariat Direktorat Jenderal Perhubungan Udara. Data were processed using multiple regression. Based on Instrument test used validity and reliability test, it can conclused that all item questionnaires are valid and reliable. Hypothesis test (F-test and t-test) is conducted after successfully tested the classical assumption test that is multicollinearity, heteroscedasticity and normality. The calculation of correlation coefficient is conducted with the help of SPSS software version 25.0.

\section{RESULTS AND DISCUSSIONS}

\section{A. Characteristic of Respondents}

The characteristic of respondents answes show that there are $52(67.53 \%)$ male and there are25 (32.47\%) female. Based on education level, Bachelor degree are 52 respondents $(67.53 \%), 17$ respondents $(22.08 \%)$ had Master degree, 6 respondents $(7.79 \%)$ had associate degree, and 2 respondents $(2.6 \%)$ had a Senior High School education. Based on years of service, 15 respondents (19.48\%) work less than 5 years, 52 respondents $(67.53 \%)$ have tenure between 5-10 years, and 10 respondents (12.99\%) have working period of more than 10 years.

\section{B. Analysis Data}

\section{Instrument Test}

The instrument were tested validity and reliability test. Validity test is conducted by using Pearson Product Moment. The results of validity testing show that all indicators are valid data. In addition, reliability test show that all variables are reliable, this is because each has a value of cronbach's alpha $>0.60$.

The results of the classical assumption test, show that the normality test is met because the significant value obtained greater than 0.05 . The results of multicollinearity test show that between work discipline, work motivation and compensation variable were not correlated or multicollinearity was not applied in the regression model because it obtained VIF value $<10$ and Tolerance $>0.1$. The results of heteroscedasticity test show that three variables are free from heteroscedasticity problem because in the independent variable has significant value $>0.05$.
Hypothesis Testing Simultaneously (F-test)

The results of hypothesis testing with F-test can be seen in Figure 2.

\begin{tabular}{|c|c|c|c|c|c|}
\hline \multicolumn{7}{|c|}{ ANOVA } \\
\hline Model & $\begin{array}{c}\text { Sum of } \\
\text { Squares }\end{array}$ & df & $\begin{array}{c}\text { Mean } \\
\text { Square }\end{array}$ & F & Sig. \\
\hline Regression & 6.124 & 3 & 2.041 & 148.087 & .000 \\
\hline Residual & 1.006 & 73 & 0.014 & & \\
\hline Total & 7.130 & 76 & & & \\
\hline \multicolumn{7}{|c|}{ Fig 2:- F-test }
\end{tabular}

Based on Figure 2 above, the results of F-test obtained a F-value of 148.087 and a significant value of 0.000 is less than 0.05. This conclude that work discipline, work motivation and compensation simultaneously have a significant effect on the employees performance.

\section{Hypothesis Testing Partially (t-test)}

Basic decision-making based on the value of significance, if the significance value is smaller than the error rate of $5 \%$ (sig. < 0.05$)$ them Ho is rejected. The test results are summarized in Figure 3 below.

\begin{tabular}{|c|c|c|c|c|}
\hline \multicolumn{5}{|c|}{ Coefficients } \\
\hline \multirow{2}{*}{ Model } & \multicolumn{2}{|c|}{$\begin{array}{c}\text { Ustandardizes } \\
\text { Coefficients }\end{array}$} & \multirow{2}{*}{$\mathbf{t}$} & \multirow{2}{*}{ Sig. } \\
\hline & B & $\begin{array}{l}\text { Std. } \\
\text { Error }\end{array}$ & & \\
\hline (Constant) & 1.548 & 0.110 & 14.017 & 0.000 \\
\hline Work Discipline & 0.190 & 0.027 & 7.107 & 0.000 \\
\hline Work Motivation & 0.266 & 0.037 & 7.161 & 0.000 \\
\hline Compensation & 0.170 & 0.025 & 6.690 & 0.000 \\
\hline
\end{tabular}

Fig 3:- Multiple Regression Test

Based on Figure 3 can be explained about the results of the t-test hypothesis as follows:

\section{- Work Discipline}

H1. Work discipline has significant and positive effect on employee performance.

From the Figure 3, it demonstrate work discipline towards employees performance is significant; the p-value (Sig.0) is 0.000 , less than 0.05 significant levels. In other words, work discipline has a significant positive effect on employees performance.

\section{- Work Motivation}

H2. Work motivation has significant and positive effect on employee performance.

From the Figure 3, it demonstrate work motivation towards employees performance is significant; the p-value (Sig.0) is 0.000 , less than 0.05 significant levels. In other words, work motivation has a significant positive effect on employees performance. 


\section{- Compensation}

H3. Compensation has significant and positive effect on employee performance.

From the Figure 3, it demonstrate compensation towards employees performance is significant; the $\mathrm{p}$-value (Sig.0) is 0.000 , less than 0.05 significant levels. In other words, compensation has a significant and positive effect on employees performance.

\section{Determination Coefficient ( $R$-Square)}

The test results of determination coefficient can be seen in below.

\begin{tabular}{|c|c|c|c|c|}
\hline \multicolumn{5}{|c|}{ Model Summary } \\
\hline Model & R & R Square & $\begin{array}{c}\text { Adjusted } \\
\text { R Square }\end{array}$ & $\begin{array}{c}\text { Error of } \\
\text { The } \\
\text { Estimate }\end{array}$ \\
\hline 1 & .927 & 0.859 & 0.853 & 0.117 \\
\hline
\end{tabular}

Fig 4:- Determination Coefficient Test (R-Square)

Based on determination coefficient test obtained the Adjusted R Square value of 0.853 . This means that $85.3 \%$ variation on employees performance is influenced by work discipline, work motivation and compensation while the remaining $14.7 \%$ employee performance variation is influenced by other variables outside this study.

\section{* Discussion}

The hypothesis results show that $\mathrm{H} 1$ is accepted and concluded that work discipline has a positive and significant effect on employee performance. The same results were also found by Tumilaar (2015) and Wairooy (2017) that discipline has a significant positive effect on employee performance. Furthermore, H2 is accepted and concluded that work motivation has a positive and significant effect on employee performance. This is supported by research Akbar (2015) and Alwi (2017) which states that work motivation has a significant effect on employee performance. Hypothesis results show that $\mathrm{H} 3$ is accepted and concluded that Compensation has a positive and significant effect on Employee Performance. This is in line with research by Thaief, et al. (2015) and Astutik (2016) which stated that compensation had a significant effect on employee performance.

\section{CONCLUSIONS AND RECOMMENDATIONS}

\section{A. Conclusion}

Based on the results of research and discussion on the effect of work discipline, work motivation and compensation on employee performance at the Sekretariat Direktorat Jenderal Perhubungan Udara conclusions can be drawn as follows:

$>$ Work discipline has a positive and significant impact on employee performance

$>$ Work motivation has a positive and significant effect on employee performance

$>$ Compensation has a positive and significant impact on employee performance

\section{B. Recommendation}

From the results of this research conducted by the author were given some suggestions as follows:

\section{$>$ For Organizations}

- It is recommended that leaders provide intrinsic motivation in the form of attention, appreciation or reward for the achievements, and comfort in order to be able to shape employee morale in working better. Agencies and leaders can provide benefits in the form of upgrading soft skills so that employee motivation increases.

- For the leader in order to improve work discipline by maintaining aspects of work discipline that already exist today. Leaders are advised to always supervise employees to work according to the agency's standard operating procedures. Leaders must be firm in their actions and also give examples of disciplinary behavior to employees by giving warning letters in stages for employees who have not acted discipline. Then so that the level of employee discipline is getting better, the placement of employees must be in accordance with their expertise and education.

- It is expected that the agency can maintain and increase financial and non-financial compensation so that employee performance increases. In granting compensation, agencies are advised to be fair and balanced by conducting an objective assessment of each employee and truly based on the resulting performance. Agencies can also do a family gathering per year which is useful for building employee togetherness so that performance can improve.

\section{$>$ For Further Research}

- It is hoped that the results of this study can be used as a reference for future researchers to develop this research by considering various other variables.

- For further research can develop a more varied population and sample so that it can be input for agencies.

\section{REFERENCES}

[1]. Abdullah, Ma'aruf. (2014). Manajemen dan Evaluasi Kinerja Karyawan. Aswaja Pressindo. Yogyakarta.

[2]. Akbar, Alfian Amidhan. (2015). "Pengaruh Kompensasi, Motivasi dan Disiplin Kerja terhadap Kinerja Karyawan CV. Cemara Production Surabaya". Jurnal Ilmu dan Riset Manajemen. 4(10):1-19.

[3]. Alwi, Muhamad. (2017). "Pengaruh Kompensasi, Kompetensi dan Motivasi terhadap Kinerja Karyawan CV. XYZ". Jurnal Logika. XIX(1):73-87.

[4]. Astutik, Mardi. (2016). "Pengaruh Kompensasi dan Disiplin Kerja Terhadap Kinerja Karyawan”. Akademika. 14(2):97-92.

[5]. Dessler, Gary. (2011). Manajemen Sumber Daya Manusia. Penerbit Indeks. Jakarta.

[6]. Handoko, T Hani. (2008). Manajemen Personalia dan Sumber Daya Manusia. BPFE. Yogyakarta. 
[7]. Hasibuan, Malayu S.P. (2014). Manajemen Sumber Daya Manusia Edisi Revisi. Bumi Aksara. Jakarta.

[8]. Kasmir. (2016). Manajemen Sumber Daya Manusia (Teori dan Praktik). Raja Grafindo Persada. Jakarta.

[9]. Nurjaman, Kadar. (2014). Manajemen Personalia. Pustaka Setia. Bandung.

[10]. Rivai, Veithzal. (2014). Manajemen Sumber Daya Manusia Untuk Perusahaan Dari Teori Ke Praktik. PT Rajagrafindo Persada. Jakarta.

[11]. Robbins, S. P., dan Judge, Timothy A. (2015). Perilaku Organisasi Edisi Enam Belas Salemba Empat. Jakarta.

[12]. Siagian, Sondang P. (2009). Kiat Meningkatkan Produktivitas Kerja. PT Rineka Cipta. Jakarta.

[13]. Thaief, Ilham; Aris B, Priyono \& Mohamad S I. (2015). "Effect of Training, Compensation and Work Discipline against Employee Job Performance (Studies in the Office of PT. PLN (Persero) Service Area and Network Malang)". Review of European Studies. 7(11):23-33.

[14]. Tumilaar, Brigita Ria. (2015). "The Effect of Dicipline, Leadership, and Motivation On Employee Performance at BPJS Ketenagakerjaan Sulut”. Jurnal EMBA. 3(2):787-797.

[15]. Wairooy, Ali. (2017). "Pengaruh Disiplin Kerja dan Kompensasi terhadap Kinerja Karyawan pada PT Pertamina (Persero), Tbk. Pemasaran Region VII Makassar". Jurnal Administrare: Jurnal Pemikiran Ilmiah dan Pendidikan Administrasi Perkantoran. 4(1):15-24. 